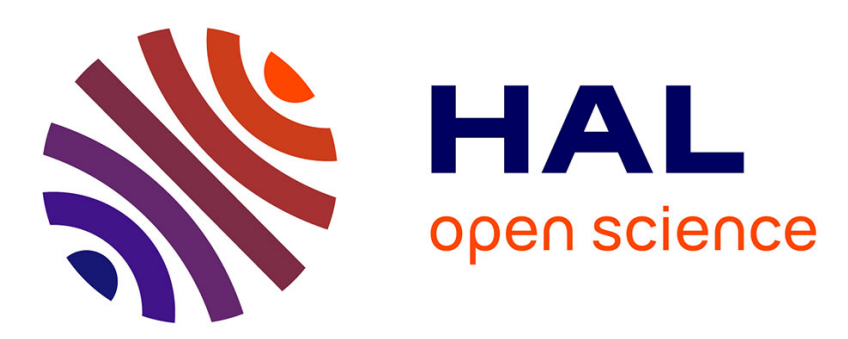

\title{
Postnatal expression of zinc- $\alpha$-glycoprotein in rat white and brown adipose tissue
}

Theodora Tzanavari, Chen Bing, Paul Trayhurn

\section{To cite this version:}

Theodora Tzanavari, Chen Bing, Paul Trayhurn. Postnatal expression of zinc- $\alpha$-glycoprotein in rat white and brown adipose tissue. Molecular and Cellular Endocrinology, 2007, 279 (1-2), pp.26. 10.1016/j.mce.2007.08.015 . hal-00531949

\section{HAL Id: hal-00531949 \\ https://hal.science/hal-00531949}

Submitted on 4 Nov 2010

HAL is a multi-disciplinary open access archive for the deposit and dissemination of scientific research documents, whether they are published or not. The documents may come from teaching and research institutions in France or abroad, or from public or private research centers.
L'archive ouverte pluridisciplinaire HAL, est destinée au dépôt et à la diffusion de documents scientifiques de niveau recherche, publiés ou non, émanant des établissements d'enseignement et de recherche français ou étrangers, des laboratoires publics ou privés. 


\section{Accepted Manuscript}

Title: Postnatal expression of zinc- $\alpha_{2}$-glycoprotein in rat white and brown adipose tissue

Authors: Theodora Tzanavari, Chen Bing, Paul Trayhurn

PII: $\quad$ S0303-7207(07)00336-X

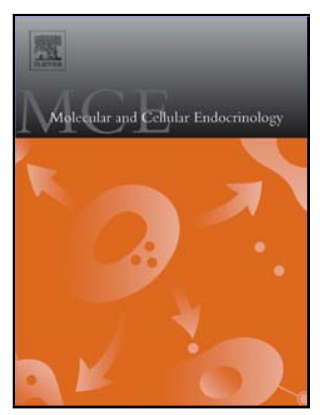

DOI: doi:10.1016/j.mce.2007.08.015

Reference: $\quad$ MCE 6704

To appear in: $\quad$ Molecular and Cellular Endocrinology

Received date: 6-7-2007

Revised date: $\quad$ 17-8-2007

Accepted date: $\quad 30-8-2007$

Please cite this article as: Tzanavari, T., Bing, C., Trayhurn, P., Postnatal expression of zinc- $\alpha_{2}$-glycoprotein in rat white and brown adipose tissue, Molecular and Cellular Endocrinology (2007), doi:10.1016/j.mce.2007.08.015

This is a PDF file of an unedited manuscript that has been accepted for publication. As a service to our customers we are providing this early version of the manuscript. The manuscript will undergo copyediting, typesetting, and review of the resulting proof before it is published in its final form. Please note that during the production process errors may be discovered which could affect the content, and all legal disclaimers that apply to the journal pertain. 


\section{Postnatal expression of zinc- $\alpha_{2}$-glycoprotein in rat white and brown adipose tissue}

Theodora Tzanavari, Chen Bing* and Paul Trayhurn

Obesity Biology Unit, Division of Metabolic \& CellularMedicine, School of Clinical Sciences, University of Liverpool, Liverpool L69 3GA, UK

*Corresponding author:

Tel: +44-151-7064075

Fax: $+44-151-7065082$

E-mail address: bing@liverpool.ac.uk

Keywords: Zinc- $\alpha_{2}$-glycoprotein; Adipokine; Development; Adipose tissue 


\begin{abstract}
Zinc- $\alpha_{2}$-glycoprotein (ZAG), a lipid-mobilizing factor, is a novel adipokine which may act locally to influence adipose tissue metabolism. This study examined the ontogeny of ZAG expression in adipose tissue during postnatal development. White (subcutaneous, gonadal, and perirenal) and brown (interscapular) fat was collected from rats aged 1 to 32 days. ZAG mRNA was detected from day 1 in subcutaneous fat, which appears the key site of synthesis postnatally. ZAG was detected in perirenal (day 5) and in gonadal (day 7) fat when the tissue was sufficient for analysis. ZAG mRNA and protein levels fell significantly at the weaning (day 21) and thereafter. ZAG was also detected in brown fat at day 1 but it fell significantly afterwards. The downregulated ZAG expression in white fat depots at the weaning, when fat mass is expanded substantially, suggests that ZAG might be involved in the postnatal development of adipose tissue mass.
\end{abstract}




\section{Introduction}

Zinc- $\alpha_{2}$-glycoprotein $(\mathrm{ZAG})$ is a $43 \mathrm{kDa}$ glycoprotein, first isolated from human plasma (Burgi \& Schmid, 1961), and later found in secretory epithelial cells of the liver, breast, gastrointestinal tract and sweat glands (Tada et al., 1991). ZAG is overexpressed in several types of malignant tumour, and has thus been used as a cancer marker (Diez-Itza et al., 1993; Hale et al., 2001). Its biological functions are largely unknown; however ZAG has been demonstrated to act as a lipid-mobilising factor (Hirai et al., 1998; Todorov et al., 1998). Treatment with ZAG stimulates lipolysis in isolated mouse and human adipocytes, and induces a rapid and selective reduction in body fat both in normal and $o b / o b$ mice (Hirai et al., 1998). This lipolytic action may be mediated via the $\beta_{3}$-adrenoreceptor with upregulation of cAMP (Russell et al., 2002). Recent work has shown the increased body weight of ZAG deficient mice subjected to a high fat diet and this is probably due to significantly reduced lipolysis in adipocytes (Rolli et al., 2006). Rat and human ZAG display 59\% amino acid sequence homology (Ueyama et al., 1994) but share up to $100 \%$ identity in specific regions thought to be important in lipid metabolism (Sanchez et al., 1999).

White adipose tissue (WAT) is now recognised as a major endocrine and secretory organ (Ahima \& Flier, 2000; Trayhurn \& Beattie, 2001), adipocytes expressing and secreting a wide range of protein factors, termed adipokines. These adipokines include leptin, adiponectin, tumour necrosis factor $\alpha(\mathrm{TNF} \alpha)$, and interleukin-6 (IL-6), which act in autocrine, paracrine and/or endocrine manner to regulate energy balance and other physiological processes, such as the inflammatory response (Trayhurn \& Wood 2004). Our recent work has identified ZAG as an adipokine since it is expressed in adult mouse WAT and brown adipose tissue (BAT) (Bing et al., 2004) and subsequently found to be secreted by adipocytes (Bao et al., 2005). ZAG expression appears to be related to fat mass, its levels being increased in cachexia (Bing 
et al., 2004; Bing et al., 2006), while reduced in obesity (Dahlman et al., 2005), suggesting that it may regulate lipid metabolism locally.

The occurrence and expression patterns of ZAG during postnatal development when adipose tissue undergoes major morphological and metabolic changes that result in a considerable expansion of body fat mass (Herrera \& Amusquivar, 2000) are not known. There is also little information on whether there are depot differences in expression levels during this period. At day 1 after birth, fat is barely detectable in the rat, usually solely in the subcutaneous area and not internally; however, rats rapidly lay down fat stores during the suckling period, when the internal fat depots appear in tiny amounts, only to expand after weaning at around day 21 (Greenwood \& Hirsch, 1974; Cryer \& Jones, 1979). In contrast to WAT, BAT, which serves as a major site for adaptive thermogenesis through mitochondrial uncoupling protein-1 (UCP-1), is the first form of adipose tissue to appear during development and is present at the time of birth in rodents (Cannon et al., 1988).

In the present study we have examined the early postnatal development of ZAG production in the rat to determine the stage at which the potential for the involvement of this factor in adipose tissue regulation first occurs and how it changes in WAT and BAT during early postnatal development in the rat. Since the distribution of a particular factor in different depots might also undergo changes during development (Oliver et al., 2001a, b; Oliver et al., 2003), we have compared the inter-depots differences of ZAG expression at different time points. Leptin, the expression of which increases as fat stores are laid down during early development (Devaskar et al 1997; Rayner et al., 1997) and subsequently in several depots of rats (Oliver et al., 2001b), was also studied as a reference point. The pattern of adiponectin expression during early postnatal development was also studied since this adipokine has been linked to body weight control, obesity and insulin sensitivity, as well as inflammation, in 
adipose tissue (Trayhurn \& Wood, 2004) and a link between ZAG and adiponectin has been suggested (Gohda et al., 2003).

\section{Materials and methods}

\subsection{Animals}

Litters of female Wistar rats from an inbred colony at the University of Liverpool were housed at an ambient temperature of $22 \pm 1{ }^{0} \mathrm{C}$ under a $12: 12 \mathrm{~h}$ light-dark cycle (lights on at 0700 hours). Litter sizes were similar for each age point. Rats were weaned at postnatal day 21 and given free access to CRN chow (Dietex International, Essex, UK) and water. Six animals were killed by cervical dislocation and decapitation at 1, 3, 5, 7, 10, 21 and 32 days of age. WAT from the subcutaneous region and from the gonadal and perirenal fat depots, as well as interscapular BAT, were dissected when of sufficient size to be sampled. Tissues were immediately frozen in liquid nitrogen and stored at $-80^{\circ} \mathrm{C}$ until analysis. The weights of the pups and of the dissected tissues were recorded. The animal study was conducted according to the U.K. Home Office Guidelines for the care and use of laboratory animals.

\subsection{RNA isolation and RT-PCR}

Total RNA was extracted from tissues (50-120mg) with TRIzol (Invitrogen, Paisley, UK). RNA samples used for first strand DNA synthesis were treated with a DNA-free kit (Ambion, Cambridgeshire, UK) to remove any genomic DNA. The RNA concentration was determined from the absorbance at $260 \mathrm{nM}$. One $\mu \mathrm{g}$ of total RNA was reverse transcribed to cDNA using a Reverse-iT first strand synthesis kit (ABgene, Epsom, U.K.) according to the manufacturer's instructions. Samples of the reaction were amplified in a PCR mixture containing $0.02 \mathrm{mM}$ of each primer and 1.1x Reddy Mix PCR master mix (Abgene). Rat $\beta$ actin was used as a housekeeping gene. 
The following primer pairs were used:

rat ZAG, 5'-AAATAACAGAAGCAGTGGAGCAG-3' (forward),

5'- TTTGTGGGTAGAAGTCATAGGC-3' (reverse);

rat $\beta$-actin, 5'- GCCCATCTATGAGGGTTACGC-3' (forward),

5'- GAGCCACCAATCCACACAGAG-3' (reverse).

PCR was performed on a thermal cycler (Hybaid, Middlesex, UK) with an initial denaturation at $94^{\circ} \mathrm{C}$ for $2 \mathrm{~min}$ followed by 30 cycles of denaturation at $94^{\circ} \mathrm{C}$ for $20 \mathrm{sec}$, annealing at $54^{\circ} \mathrm{C}$ for $30 \mathrm{sec}$, and extension at $72^{\circ} \mathrm{C}$ for $1 \mathrm{~min}$. For rat $\beta$-actin, amplification was achieved with 23 cycles consisting of $94^{\circ} \mathrm{C}$ for $20 \mathrm{sec}, 64^{\circ} \mathrm{C}$ for $30 \mathrm{sec}$, and $72^{\circ} \mathrm{C}$ for $40 \mathrm{sec}$. The final step was extension at $72 \mathrm{C}^{\circ}$ for $5 \mathrm{~min}$. PCR products were separated on a $1 \%$ agarose gel stained with ethidium bromide and images were recorded. PCR products were sequenced commercially (MWG Biotech, Germany) to confirm their identity.

\subsection{Real-Time PCR}

Relative ZAG, leptin, and adiponectin levels were quantified with an Mx3005 QPCR system (Stratagene, Amsterdam, Netherlands), using primers and Taqman probes designed with PRIMER EXPRESS software (Applied Biosystems, Cheshire, UK). The sequence of the primer pairs and probes are given in Table 1 .

Amplification was performed in a 96-well plate in a final reaction volume of $12.5 \mu 1$, and each sample contained $1 \mu \mathrm{l}$ of cDNA (equivalent to $50 \mathrm{ng}$ of RNA), $900 \mathrm{nmol}$ of specific primers, $225 \mathrm{nmol}$ of the probe and a master mix made from quantitative PCR core kit (Eurogentec, Hampshire, UK). The PCR parameters were as follows: $2 \min$ at $50^{\circ} \mathrm{C}$, denaturation at $95^{\circ} \mathrm{C}$ for $10 \mathrm{~min}$, followed by 40 cycles of denaturation at $95^{\circ} \mathrm{C}$ for $15 \mathrm{sec}$ and combined annealing and extension at $60^{\circ} \mathrm{C}$ for $1 \mathrm{~min}$. 
Each quantitative PCR reaction was repeated in duplicate, and the mean value of $\mathrm{Ct}$ for each sample was used for data analysis with MxPro QPCR software (Stratagene). Each sample was normalised to the $\beta$-actin value and the results expressed as fold changes of $\mathrm{Ct}$ value relative to controls by using the $2^{-\Delta \Delta \text { ct }}$ formula (Livak \& Schmittgen, 2001). $\beta$-actin was used as a reference gene since there were no statistically significant differences in the $\mathrm{Ct}$ values between any of the time points tested (all $P>0.05$ ).

\subsection{Western blotting}

WAT and BAT protein samples were isolated from TRIzol (Invitrogen) extracts according to the manufacturer's instructions. The protein concentration was determined using the bovine serum albumin assay (Wiechelman et al., 1988). Samples containing $10 \mu \mathrm{g}$ of protein were mixed with equal volumes of $2 \mathrm{xSDS}$ loading buffer, incubated at $95^{\circ} \mathrm{C}$ for $5 \mathrm{~min}$, and separated by electrophoresis on 10\% SDS-polyacrylamide gels. Proteins were then transferred to a nitrocellulose membrane (Hybond C, Amersham Pharmacia, U.K.) and immunodetection was performed using a mouse monoclonal antibody to human ZAG (Santa Cruz Biotechnology, California, USA). The antibody was used at $4^{\circ} \mathrm{C}$ overnight at a $1: 1000$ dilution in Tris buffered saline (pH 7.4) containing 0.1\% Tween 20 and 3\% dried milk. Blots were then incubated for $1 \mathrm{~h}$ at room temperature with a rabbit anti-mouse secondary antibody conjugated to horseradish peroxidase (Santa Cruz Biotechnology) at a 1:2000 dilution. Signals were detected by enhanced chemiluminescence (ECL, Amersham Biosciences, Buckinghamshire, UK). The size of the bands detected was estimated by using protein rainbow molecular-mass standards (Amersham Biosciences). Autoradiographs were scanned and the intensity of signals analysed using PHORETIX 1D advanced software. Equal protein loading was confirmed by staining the gel with Ponceau S. 


\subsection{Statistical analysis}

Data were expressed as mean values \pm SEM (bars). Differences between two groups were analysed by Student's unpaired $t$ test, while comparisons among more than two groups were assessed by one-way ANOVA coupled with Bonferroni's tests. Differences were considered as statistically significant when $P<0.05$.

\section{Results}

\subsection{ZAG expression in adipose tissue of neonatal rats}

At birth there was very little dissectable WAT in the rats, although substantial amounts appeared over the first few days of life in the subcutaneous region. There was little abdominal WAT before 10 days of age, fat being rapidly deposited in perirenal and gonadal depots thereafter (Fig. 1A \& 1B). As a percentage of body weight, the amount of interscapular BAT was substantial at day 1 and the following few days after birth; a trend towards a decrease appeared to occur at day 3 but this was not statistically significant (Fig. 1C). BAT amount fell progressively from 5 days of age onwards, the reduction being statistically significant at days 15, 21 and 32 (Fig. 1C). The expression pattern of ZAG was initially examined in the neonatal adipose tissues by RT-PCR and western blotting. ZAG mRNA was detected in subcutaneous WAT and BAT from pups at day 1 of age (Fig. 2A). A strong signal for ZAG protein was also detected in BAT at day 1 and day 3 after birth (Fig. 2B).

Since ZAG is expressed in rat adipose tissue at day 1 postnatally, the ontogenic pattern of expression during early postnatal development was investigated. Real-time PCR revealed no significant differences in ZAG mRNA levels in the subcutaneous depot at the different time points examined between 1 and 32 days of age (Fig. 3A). The earliest age at which there was sufficient perirenal and gonadal WAT to permit analysis was days 5 and 7, respectively. Both ZAG mRNA and protein were detected in these depots at these early 
stages. In contrast to subcutaneous fat, ZAG mRNA level in perirenal WAT was significantly decreased at day $32(P<0.05)$ (Fig. 3B). In gonadal WAT ZAG mRNA levels were higher between day 7 and day 15 after birth, but were substantially reduced at day $21(P<0.01)$ and day $32(P<0.05)$ (Fig. 3C). We have further examined the pattern of ZAG protein

expression in the three WAT depots of neonatal rats using immunoblotting. ZAG protein levels in subcutaneous and perirenal depots were significantly reduced at day 21 and day 32 compared to day 7 (all $P<0.01$ ) (Fig. 4A \& B). In gonadal fat, ZAG protein fell markedly at day 32 relative to its levels at day $7(P<0.001)$ (Fig. 4C).

ZAG mRNA was readily detected in the interscapular BAT of rats at day 1 of age. In marked contrast to the WAT depots, ZAG mRNA levels in BAT fell sharply ( $>5$-fold) between days 1 and 3 after birth and fell further thereafter (Fig. 3D), while protein levels were reduced both at day 21 and day 32 compared to day 7 (both $P<0.01$ ) (Fig. 4D).

\subsection{Leptin and adiponectin expression in adipose tissue of neonatal rats}

The postnatal changes in leptin and adiponectin mRNA were measured as a comparison to the patterns of expression observed for ZAG mRNA. Leptin mRNA levels in subcutaneous WAT increased substantially ( $>75$-fold) between days 1 and 3 (Fig. 5A) reaching a peak at day 15 , when they were almost 250 -fold higher than at day $1(P<0.001)$. The level of leptin mRNA, slightly declined at weaning and at day 32. In perirenal WAT (Fig. 5B), leptin mRNA levels gradually increased from day 1 , reaching a peak at day 32, at which point they were $\sim 20$ fold higher compared to day $1(P<0.001)$. In gonadal WAT, the pattern of leptin gene expression was much more variable than for the other two WAT depots. Leptin mRNA levels were low late in the suckling period and at weaning, but increased markedly by day $32(P<$ 0.05) (Fig. 5C). Similar to subcutaneous WAT, leptin mRNA levels in BAT were 
significantly increased from day 3, peaking at day 10 when they were $\sim 22$ fold higher compared to day $1(P<0.001)$ (Fig. 5D).

Similar to what was observed for leptin, adiponectin mRNA levels in the subcutaneous depot (Fig. 5A) were significantly increased, reaching a $\sim 5$-fold increase at day $15(P<0.05)$; between days 3 and 32 there was little change in adiponectin mRNA level. In the perirenal depot (Fig. 5B), there was a gradual increase in adiponectin mRNA from day 1, the level being highest at day $32(\sim 8$-fold higher compared to day 1$)(P<0.001)$. As in the perirenal depot, the level of adiponectin in gonadal WAT was higher after weaning than during the suckling period (Fig. 5C). However, no changes were observed in the levels of adiponectin mRNA in BAT until day 32 (Fig. 5D).

\subsection{Depot differences in ZAG expression in adipose tissue during postnatal development}

Although RT-PCR analysis has shown that ZAG is expressed early in postnatal life in all adipose tissue depots examined, differences in the mRNA level were evident between the different sites. In order to explore whether the pattern of depot differences changes at different stages during postnatal development, ZAG mRNA levels were compared at day 1 in BAT and subcutaneous WAT and at days 7 and 32 in subcutaneous, perirenal, and gonadal WAT and BAT. At day 1, ZAG mRNA levels were higher $(\sim 18$-fold $)(P<0.01)$ in subcutaneous WAT compared to BAT. At both days 7 and 32, ZAG mRNA was still significantly more abundant in the subcutaneous depot compared with both BAT and the other WAT depots (both $P<$ 0.001) (Fig. 6A). A different pattern of relative expression was observed in the case of leptin (Fig. 6B) and adiponectin (Fig. 6C). At day 1 postnatally, leptin mRNA levels were significantly higher in BAT ( $\sim 12$-fold) compared to subcutaneous WAT $(P<0.01)$. By day 7 however, leptin levels were higher in subcutaneous $(\sim 10$-fold) compared to perirenal WAT $(P$ $<0.001$ ), while still quite high in BAT. This pattern was completely changed by day 32 , when 
leptin mRNA was more abundant in the internal WAT depots, leptin levels being 4-fold higher in gonadal compared to subcutaneous WAT $(P<0.01)$ (Fig. 6B). At day 1, adiponectin mRNA levels were similar in BAT and subcutaneous WAT, while at day 7 the concentration in the latter was increased by $\sim 3$-fold $(P<0.05)$; at day 32, however, adiponectin mRNA levels were $\sim 20$-fold higher in gonadal $(P<0.05)$ and $\sim 7$-fold in perirenal WAT compared to $\operatorname{BAT}(P<0.05)($ Fig. 6C).

\section{Discussion}

Little is known about the onset of the ZAG system and its role in the early stages of postnatal development. The studies described here demonstrate that ZAG, at both the mRNA and protein level, is expressed in subcutaneous WAT and BAT of one-day old rats. At this stage WAT can only be sampled from the subcutaneous region, this being the major fat depot during the suckling period. The metabolism of rat adipose tissue during early development undergoes major changes which are mainly due to alterations in the rates of lipolysis and lipogenesis (Herrera \& Amusquivar, 2000). The strong signal observed for ZAG mRNA and protein expression at day 1 postnatally suggests that ZAG might play a role in the regulation of adipose tissue metabolism from early in postnatal life.

The present study has shown that there are no major changes in ZAG mRNA levels in WAT during the suckling period. Immediately after birth and less intensively during suckling, the rate of lipolysis is enhanced (Gruen et al., 1980), while lipogenic activity is suppressed (Smith \& Kaplan, 1980). During this period, there is a rapid change from glucose to lipids as the major energy source, as only limited amounts of carbohydrates are stored (Fisher, 1976). This enhanced lipolytic activity appears to be regulated by catecholamine release, resulting in cAMP production and increased protein kinase C activity (Bahnsen et al., 1984; Kimura \& Warshaw, 1983). As a lipid-mobilising factor, ZAG stimulates lipolysis in mature adipocytes 
in vitro (Todorov et al., 1998), while administration of ZAG to mice induces a rapid reduction in body fat and increases serum free fatty acid levels via the activation of hormone-sensitive lipase through increased intracellular cAMP levels (Hirai et al., 1998). In contrast to ZAG, both leptin and adiponectin mRNA levels in subcutaneous and perirenal WAT were dramatically increased in the early postnatal period, suggesting the potential role of the hormones including in the regulation of energy balance, from early in postnatal life, as previously observed for leptin (Rayner et al., 1997).

The subcutaneous fat appears to be the key adipose tissue source of ZAG, leptin and adiponectin during the suckling period. Although in adult rodents the visceral fat is metabolically more active and the expression of most adipokines is significantly upregulated compared to subcutaneous WAT, in the early suckling period the subcutaneous depot is likely to be the main site of adipokine production. However, this pattern of expression changes considerably during the early post-weaning period, by which point the mass of the visceral fat has substantially increased.

At day 21, ZAG mRNA levels in gonadal WAT were reduced compared to both day 1 and day 15, while protein levels were reduced in subcutaneous WAT compared to day 7 and were at their minimum in the perirenal site. Weaning involves a switch from a high-fat diet in the form of milk to a high-carbohydrate diet and the changes that occurred in ZAG expression around weaning suggests that ZAG could be sensitive to nutritional change. Furthermore, the data also suggests that the decrease of ZAG synthesis might be associated with a rapid increase in lipogenic activity during this period (Gruen et al., 1980). The observation that the marked reduction in ZAG protein levels in the subcutaneous and perirenal sites at weaning would be consistent with a less demand for lipid mobilisation in white fat at this stage of the neonatal development. Although it is not possible to distinguish between development per se and changes of ZAG expression induced by the gradual weaning onto a low fat diet from the 
high fat diet of milk, the postnatal expression pattern of ZAG might reflect its role under the 'real physiological situation'.

ZAG levels (mRNA and protein), both in perirenal and gonadal WAT were highly reduced after weaning compared to early postnatal life, as revealed by mRNA and protein analysis. Both leptin and adiponectin on the other hand show a different pattern, mRNA levels being increased in perirenal and gonadal depots after weaning. Following weaning, there seems to be a switch from subcutaneous to internal adipose tissue as a source of leptin and adiponectin, this being the same pattern of differential expression that has previously been reported for leptin in adult mice (Rayner et al., 1997).

The heterogeneity of WAT and the differences between different depots are clearly evident in the current study. Although WAT undergoes major metabolic changes during early postnatal development, these probably affect specific depots to different degrees. Such differences may also be related to regional differences in the production of adipose-derived factors (Mohamed-Ali et al., 1998), which also change during the course of postnatal development, as specifically shown in the case of leptin and adiponectin in this study.

BAT is the major site of non-shivering thermogenesis in small mammals (Cannon et al., 1988) and as such plays an important role in early postnatal development. This study demonstrates that ZAG is expressed in BAT of rats by/or soon after birth. The mRNA and protein levels were at their peak at day 1 but fell significantly thereafter, which appears to parallel the postnatal changes of BAT mass albeit to a lesser degree. In contrast, mRNA levels of leptin in BAT were considerably increased from day 3 onwards while adiponectin mRNA levels were unaffected. The dramatic change in ZAG expression in BAT from day 1 indicates that ZAG may have a role in BAT function at a time when the need for thermogenesis is at its highest. Importantly, ZAG has been shown to increase UCP-1 expression in mouse BAT (Bing et al., 2002) and in primary cultured brown adipocytes (Sanders \& Tisdale, 2004). 
In conclusion, the present study demonstrates that ZAG is expressed in WAT and BAT of rat neonates from day 1 postnatally, subcutaneous WAT being the main site of expression within the adipose tissues. The ontogenic pattern of expression may be linked to the metabolic changes occurring within the tissues at different phases of postnatal development. These results suggest that ZAG might be involved in the development of adipose tissue mass during the early life of rats. 


\section{Acknowledgements}

Theodora Tzanavari was in receipt of a Studentship from the University of Liverpool. 


\section{References}

Ahima, R.S., Saper, C.B., Flier, J.S. and Elmquist, J.K., 2000. Leptin regulation of neuroendocrine systems. Front Neuroendocrinol 21, 263-307.

Bahnsen, M., Burrin, J.M., Johnston, D.G., Pernet, A., Walker, M. and Alberti, K.G., 1984. Mechanisms of catecholamine effects on ketogenesis. Am J Physiol 247, E173-80.

Bao, Y., Bing, C., Hunter, L., Jenkins, J.R., Wabitsch, M. and Trayhurn, P., 2005. Zincalpha2-glycoprotein, a lipid mobilizing factor, is expressed and secreted by human (SGBS) adipocytes. FEBS Lett 579, 41-7.

Bing, C., Bao, Y., Jenkins, J., Sanders, P., Manieri, M., Cinti, S., Tisdale, M.J. and Trayhurn, P., 2004. Zinc-alpha2-glycoprotein, a lipid mobilizing factor, is expressed in adipocytes and is up-regulated in mice with cancer cachexia. Proc Natl Acad Sci U S A $101,2500-5$.

Bing, C., Russell, S.T., Beckett, E.E., Collins, P., Taylor, S., Barraclough, R., Tisdale, M.J. and Williams, G., 2002. Expression of uncoupling proteins-1, -2 and -3 mRNA is induced by an adenocarcinoma-derived lipid-mobilizing factor. Br J Cancer 86, 612-8.

Bing, C., Russell, S., Becket, E., Pope, M., Tisdale, M.J., Trayhurn, P. and Jenkins, J.R., 2006. Adipose atrophy in cancer cachexia: morphologic and molecular analysis of adipose tissue in tumour-bearing mice. Br J Cancer 95, 1028-1037.

Burgi, W. and Schmid, K., 1961. Preparation and properties of Zn-alpha 2-glycoprotein of normal human plasma. J Biol Chem 236, 1066-74.

DA, F., 1976. Endocrine physiology. In: Physiology of the newborn infant (Nelson, S.C., ed.), pp. 554-612, Charles C Thomas, Springfield IL.

Dahlman, I., Kaaman, M., Olsson, T., Tan, G.D., Bickerton, A.S., Wahlen, K., Andersson, J., Nordstrom, E.A., Blomqvist, L., Sjogren, A., Forsgren, M., Attersand, A. and Arner, P., 2005. A unique role of monocyte chemoattractant protein 1 among chemokines in adipose tissue of obese subjects. J Clin Endocrinol Metab 90, 5834-40.

Dessolin, S., Schalling, M., Champigny, O., Lonnqvist, F., Ailhaud, G., Dani, C. and Ricquier, D., 1997. Leptin gene is expressed in rat brown adipose tissue at birth. Faseb J 11, 382-7.

Devaskar, S.U., Ollesch, C., Rajakumar, R.A. and Rajakumar, P.A., 1997. Developmental changes in ob gene expression and circulating leptin peptide concentrations. Biochem Biophys Res Commun, 238: 44-47.

Diez-Itza, I., Sanchez, L.M., Allende, M.T., Vizoso, F., Ruibal, A. and Lopez-Otin, C., 1993. Zn-alpha 2-glycoprotein levels in breast cancer cytosols and correlation with clinical, histological and biochemical parameters. Eur J Cancer 29A, 1256-60. 
Gohda, T., Makita, Y., Shike, T., Tanimoto, M., Funabiki, K., Horikoshi, S. and Tomino, Y., 2003. Identification of epistatic interaction involved in obesity using the KK/Ta mouse as a Type 2 diabetes model: is $\mathrm{Zn}$-alpha2 glycoprotein-1 a candidate gene for obesity? Diabetes 52, 2175-2181.

Greenwood, M.R. and Hirsch, J., 1974. Postnatal development of adipocyte cellularity in the normal rat. J Lipid Res 15, 474-83.

Gruen, R., Kava, R. and Greenwood, M.R., 1980. Development of basal lipolysis and fat cell size in the epididymal fat pad of normal rats. Metabolism 29, 246-53.

Hale, L.P., Price, D.T., Sanchez, L.M., Demark-Wahnefried, W. and Madden, J.F., 2001. Zinc alpha-2-glycoprotein is expressed by malignant prostatic epithelium and may serve as a potential serum marker for prostate cancer. Clin Cancer Res 7, 846-53.

Herrera, E. and Amusquivar, E., 2000. Lipid metabolism in the fetus and the newborn. Diabetes Metab Res Rev 16, 202-10.

Himms-Hagen, J., 1995. Does thermoregulatory feeding occur in newborn infants? A novel view of the role of brown adipose tissue thermogenesis in control of food intake. Obes Res 3, 361-9.

Hirai, K., Hussey, H.J., Barber, M.D., Price, S.A. and Tisdale, M.J., 1998. Biological evaluation of a lipid-mobilizing factor isolated from the urine of cancer patients. Cancer Res 58, 2359-65.

Kimura, R.E. and Warshaw, J.B., 1983. Metabolic adaptations of the fetus and newborn. J Pediatr Gastroenterol Nutr 2 Suppl 1, S12-5.

Livak, K.J. and Schmittgen, T.D., 2001. Analysis of relative gene expression data using realtime quantitative PCR and the 2-(-Delta Delta C(T)) Method. Methods 25, 402-408.

Mohamed-Ali, V., Pinkney, J.H. and Coppack, S.W., 1998. Adipose tissue as an endocrine and paracrine organ. Int J Obes Relat Metab Disord 22, 1145-58.

Oliver, P., Pico, C. and Palou, A., 2001. Differential expression of genes for uncoupling proteins 1,2 and 3 in brown and white adipose tissue depots during rat development. Cell Mol Life Sci 58, 470-6.

Oliver, P., Pico, C. and Palou, A., 2001. Ontogenesis of leptin expression in different adipose tissue depots in the rat. Pflugers Arch 442, 383-90.

Oliver, P., Pico, C., Serra, F. and Palou, A., 2003. Resistin expression in different adipose tissue depots during rat development. Mol Cell Biochem 252, 397-400.

Rayner, D.V., Dalgliesh, G.D., Duncan, J.S., Hardie, L.J., Hoggard, N. and Trayhurn, P., 1997. Postnatal development of the ob gene system: elevated leptin levels in suckling fa/fa rats. Am J Physiol 273, R446-50. 
Rolli, V., Radosavljevic, M., Astier, V., Macquin, C., Castan-Laurell, I., Visentin, V., Guigne, C., Carpene, C., Valet, P., Gilfillan, S. and Bahram, S., 2007. Lipolysis is altered in MHC class I zinc-alpha(2)-glycoprotein deficient mice. FEBS Lett 581, 394-400.

Russell, S.T., Hirai, K. and Tisdale, M.J., 2002. Role of beta3-adrenergic receptors in the action of a tumour lipid mobilizing factor. Br J Cancer 86, 424-8.

Sanchez, L.M., Chirino, A.J. and Bjorkman, P., 1999. Crystal structure of human ZAG, a fatdepleting factor related to MHC molecules. Science 283, 1914-9.

Sanders, P.M. and Tisdale, M.J., 2004. Effect of zinc-alpha2-glycoprotein (ZAG) on expression of uncoupling proteins in skeletal muscle and adipose tissue. Cancer Lett $212,71-81$.

Smith, P.A. and Kaplan, M.L., 1980. Development of hepatic and adipose tissue lipogenesis in the fa/fa rat. Int J Biochem 11, 217-28.

Tada, T., Ohkubo, I., Niwa, M., Sasaki, M., Tateyama, H. and Eimoto, T., 1991. Immunohistochemical localization of Zn-alpha 2-glycoprotein in normal human tissues. J Histochem Cytochem 39, 1221-6.

Todorov, P.T., McDevitt, T.M., Meyer, D.J., Ueyama, H., Ohkubo, I. and Tisdale, M.J., 1998. Purification and characterization of a tumor lipid-mobilizing factor. Cancer Res 58, 2353-8.

Trayhurn, P. and Beattie, J.H., 2001. Physiological role of adipose tissue: white adipose tissue as an endocrine and secretory organ. Proc Nutr Soc 60, 329-39.

Trayhurn, P. and Wood, I.S., 2004. Adipokines: inflammation and the pleiotropic role of white adipose tissue. Br J Nutr, 92, 347-355.

Ueyama, H., Naitoh, H. and Ohkubo, I., 1994. Structure and expression of rat and mouse mRNAs for Zn-alpha 2-glycoprotein. J Biochem (Tokyo) 116, 677-81.

Wiechelman, K.J., Braun, R.D. and Fitzpatrick, J.D., 1988. Investigation of the bicinchoninic acid protein assay: identification of the groups responsible for color formation. Anal Biochem 1, 231-237. 


\section{Legends to Figures}

Fig.1. Developmental changes in weight of perirenal (A) and gonadal (B) white fat depots and BAT (C) relative to body weight. Results are means \pm SE (bars) for 5 rats per group. ${ }^{*} P<$ $0.05, * * P<0.01, * * * P<0.001$

Fig.2. $Z A G$ gene expression and ZAG protein in adipose tissue of neonatal rats. (A) Detection of ZAG mRNA by RT-PCR in BAT and subcutaneous white fat from rats at day 1 and day 3 after birth; (B) Representative western blot of ZAG protein expression in BAT of the same animals. BAT, interscapular brown adipose tissue

Fig. 3. ZAG mRNA and levels in subcutaneous (A), perirenal (B), gonadal (C) and BAT (D) of newborn rats. mRNA results are expressed relative to the ZAG levels in each depot at day 1 postnatally or day 5 for perirenal and day 7 for gonadal WAT. Results are presented as means \pm SE (bars) for 5 rats per age group. ${ }^{*} P<0.05$, ${ }^{* *} P<0.01$ and $* * * P<0.001$

Fig. 4. ZAG protein levels in subcutaneous (A), perirenal (B), gonadal (C) and BAT (D) of newborn rats. Results are presented as means \pm SE (bars) for 4-5 rats at each time point. $* P<$ $0.05, * * P<0.01, * * * P<0.001$; results are relative to ZAG protein expression at day $7 .{ }^{\dagger} P<$ $0.05, \stackrel{\dagger}{\dagger} P<0.01$; results are comparisons between days 21 and 32 .

Fig.5. Relative leptin and adiponectin mRNA levels in subcutaneous (A), perirenal (B) and gonadal (C) white fat, and BAT (D) of newborn rats, measured by real-time PCR. Results are expressed relative to the levels in each depot at day 1 postnatally or day 5 for perirenal and day 7 for gonadal WAT. Results are presented as means \pm SE (bars) for 5 rats per age group. $* P<0.05, * * P<0.01$ and $* * * P<0.001$ 
Fig. 6. Relative ZAG (A), leptin (B) and adiponectin (C) mRNA levels were measured in all depots available of newborn rats at days 1, 7 and 32. Results are expressed relative to the levels of each adipokine in subcutaneous WAT at each time point and are presented as means \pm SE for 5 rats per age group. $* P<0.05, * * P<0.01, * * * P<0.001$ 
Table 1: Sequences of primer and probe sets used in real-time PT-PCR (Taqman) analyses

\begin{tabular}{llll}
\hline Gene & Sequence (5'-3') & $\begin{array}{c}\text { Conc. } \\
(\boldsymbol{n M})\end{array}$ & $\begin{array}{c}\text { Size } \\
(\boldsymbol{b} \boldsymbol{p})\end{array}$ \\
\hline rZAG & & & \\
S & CCTTCAGGAGACTGGGTCTTATTC & 900 & 99 \\
A & GTTGAGAAATGCGGTGGCTTG & 900 & \\
P & CCTCTACACCGGGTTGTCCAGGCC & 250 & \\
rLeptin & & & \\
S & AACCCTCATCAAGACCATTGTCA & 900 & 100 \\
A & CCCGGGAATGAAGTCCAAA & 900 & \\
P & TGACATTTCACACACGCAGTCGGTATCC & 250 & \\
rAdiponectin & & & \\
S & CCCCTGGCAGGAAAGGA & 900 & 64 \\
A & CCTACGCTGAATGCTGAGTGAT & 900 & \\
P & AGCCCGGAGAAGCCGCTTACATG & 250 & \\
r $\boldsymbol{s - a c t i n}$ & & & \\
S & GACAGGATGCAGAAGGAGATTACTG & 300 & 101 \\
A & GAGCCACCAATCCACACAGA & 300 & \\
P & CACCATGAAGATCAAGATCATTGCTCCTCCT & 250 & \\
\hline
\end{tabular}


A
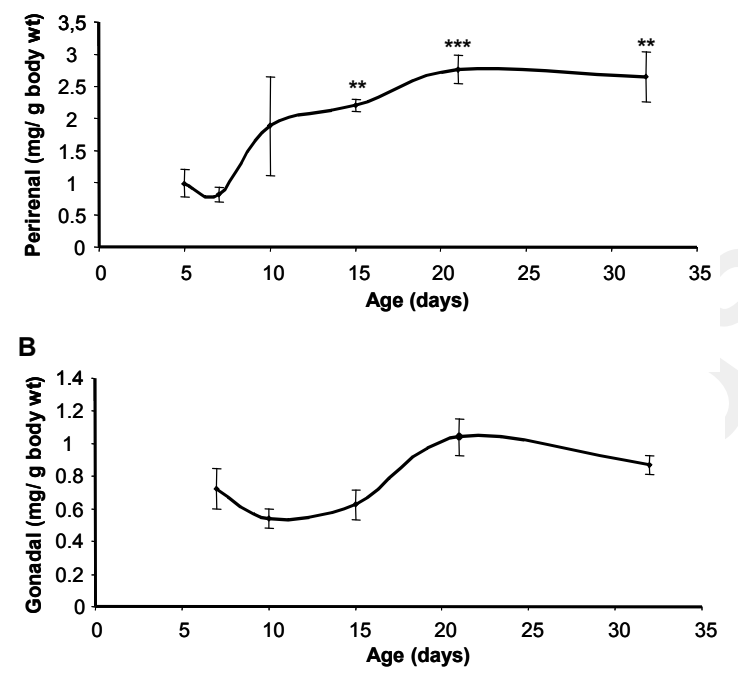

C

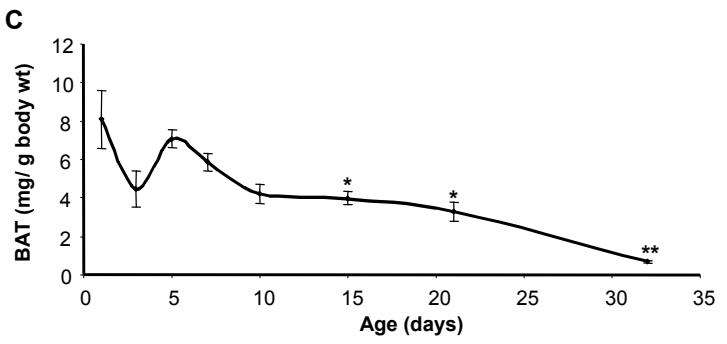

Fig.1. Developmental changes in weight of perirenal (A) and gonadal (B) white fat depots and BAT (C) relative to body weight. Results are means \pm SE (bars) for 5 rats per age group. ${ }^{*} P<$ $0.05, * * P<0.01, * * * P<0.001$ 
A

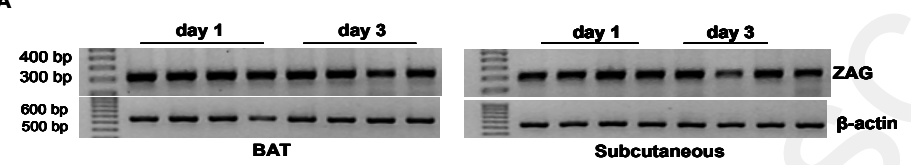

B

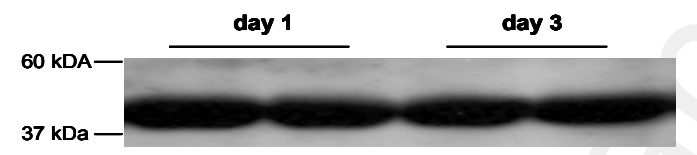

Fig.2. $Z A G$ gene expression and ZAG protein in adipose tissue of neonatal rats. (A) Detection of ZAG mRNA by RT-PCR in BAT and subcutaneous white fat from rats at day 1 and day 3 after birth; (B) Representative western blot of ZAG protein expression in BAT of the same animals. BAT, interscapular brown adipose tissue 
A. Subcutaneous

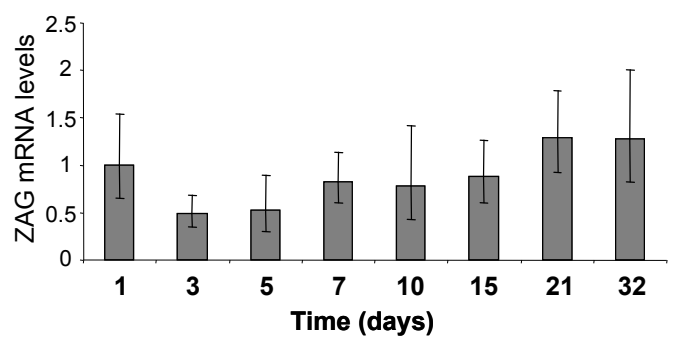

C. Gonadal

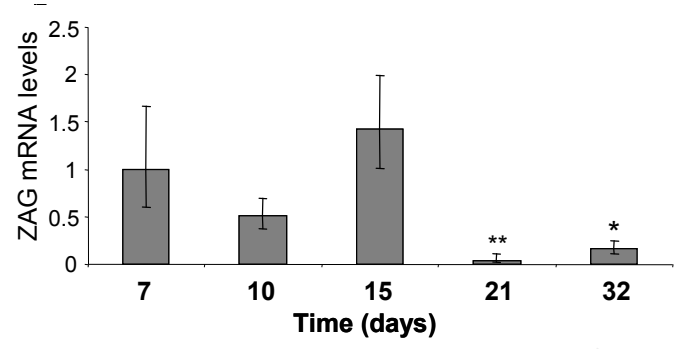

B. Perirenal

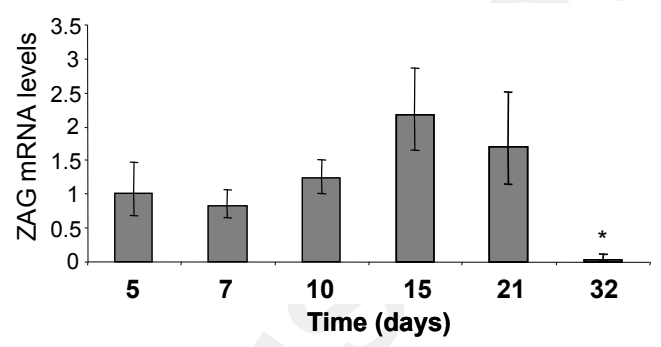

D. BAT

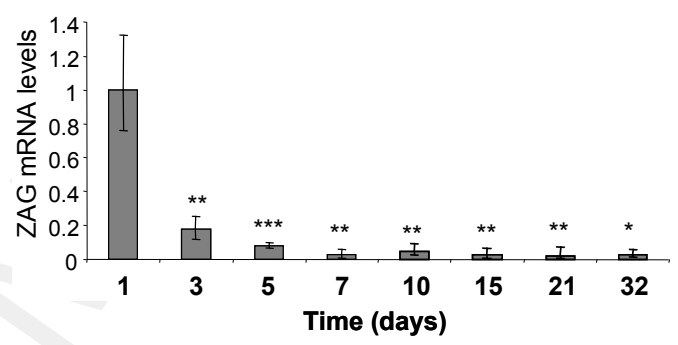

Fig. 3. ZAG mRNA and levels in subcutaneous (A), perirenal (B), gonadal (C) and BAT (D) of newborn rats. mRNA results are expressed relative to the ZAG levels in each depot at day 1 postnatally or day 5 for perirenal and day 7 for gonadal WAT. Results are presented as means \pm SE (bars) for 5 rats per age group. ${ }^{*} P<0.05, * * P<0.01$ and $* * * P<0.001$ 


\section{A. Subcutaneous}
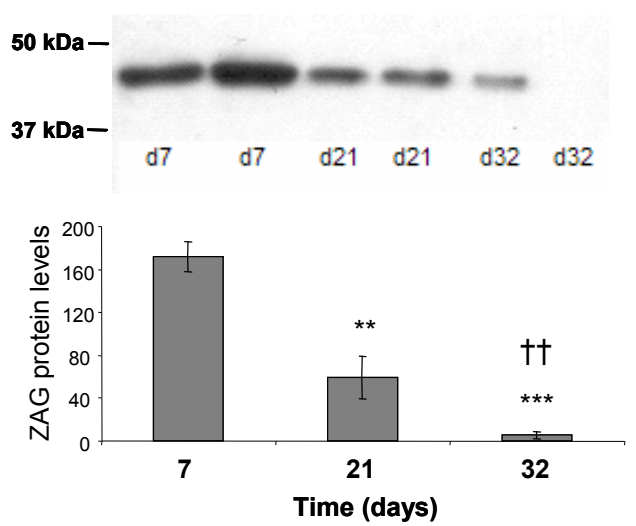

C. Gonadal
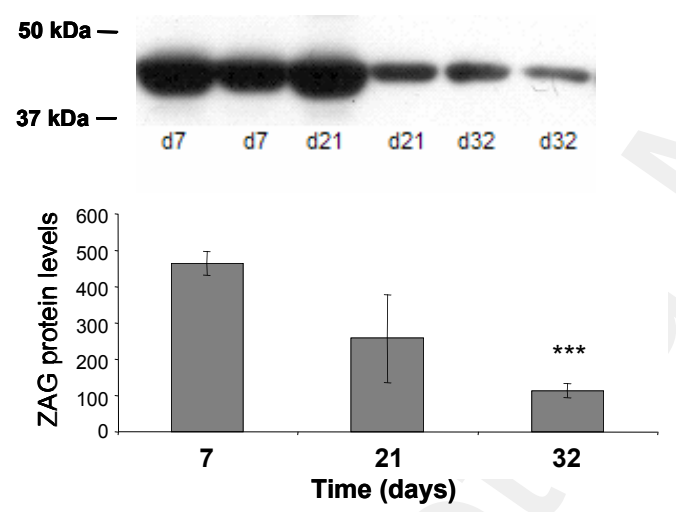

B. Perirenal
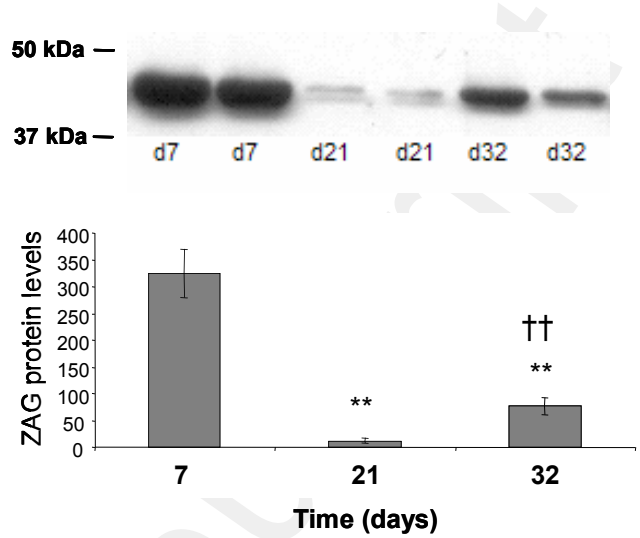

\section{BAT}
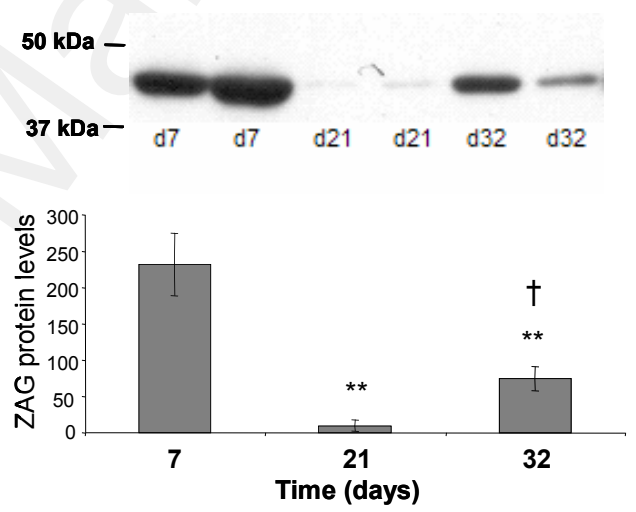

Fig. 4. ZAG protein levels in subcutaneous (A), perirenal (B), gonadal (C) and BAT (D) of newborn rats. Results are presented as means \pm SE (bars) for $4-5$ rats at each time point. $* P<$ $0.05,{ }^{*} P P<0.01,{ }^{* * *} P<0.001$; results are relative to ZAG protein expression at day $7 .{ }^{\dagger} P<$ $0.05,{ }^{\dagger} P<0.01$; results are comparisons between days 21 and 32 . 

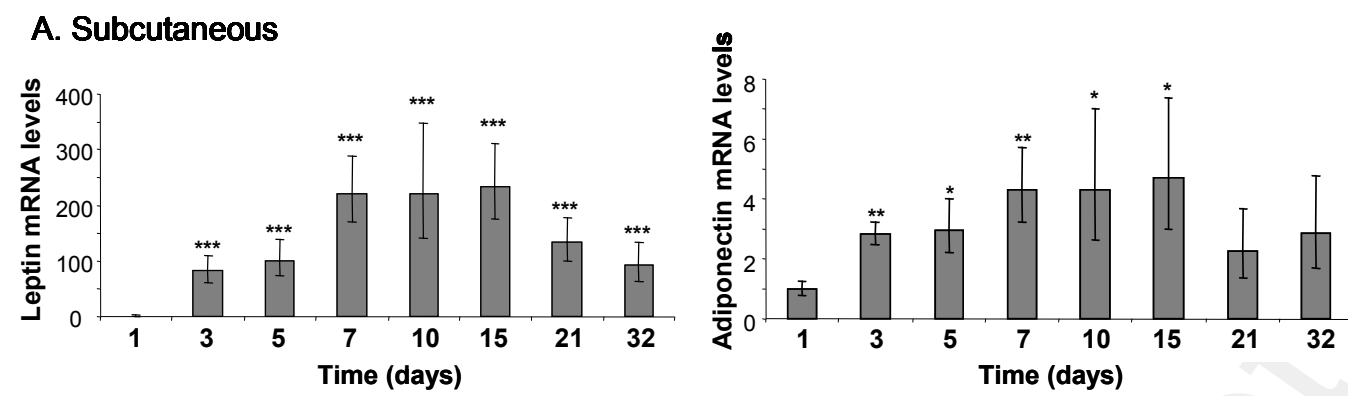

\section{B. Perirenal}
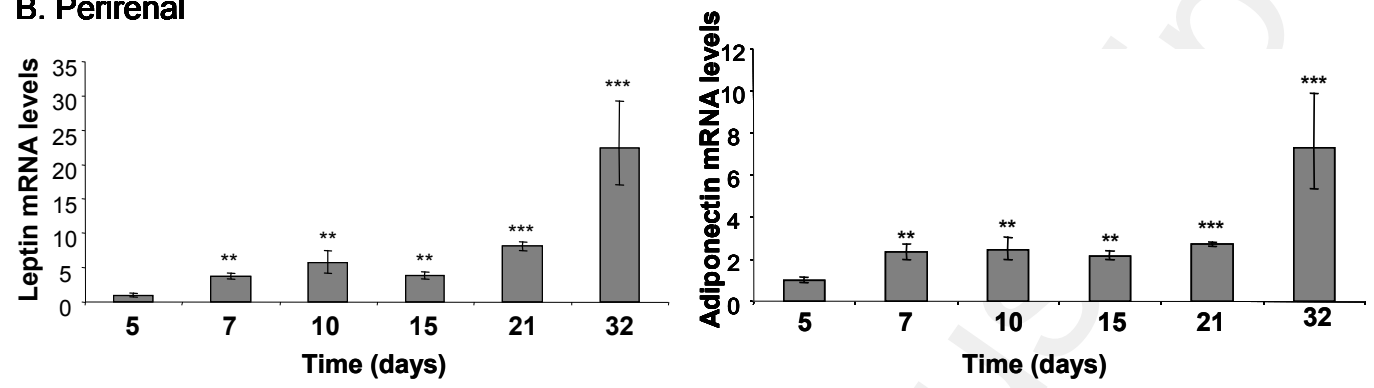

\section{Gonadal}
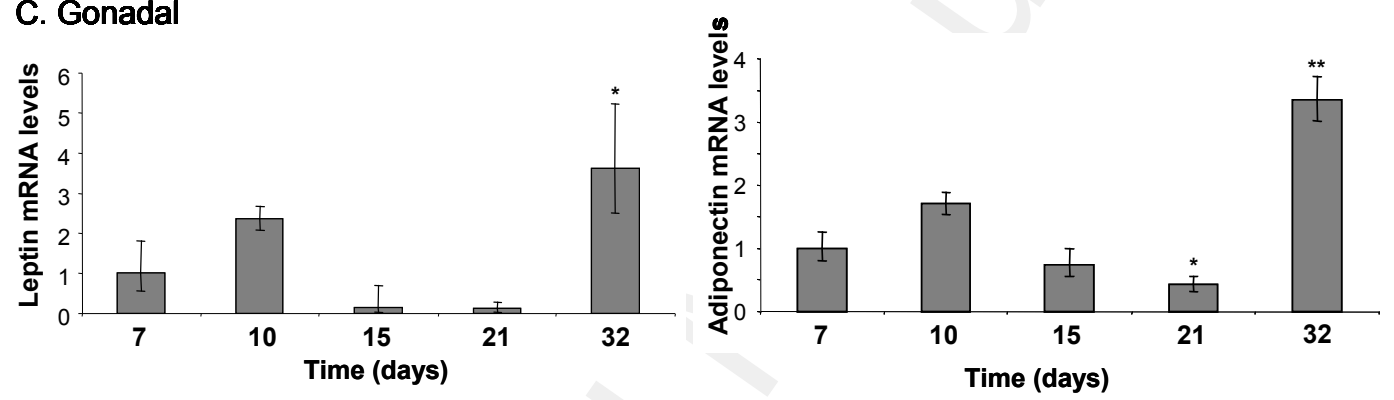

D. BAT
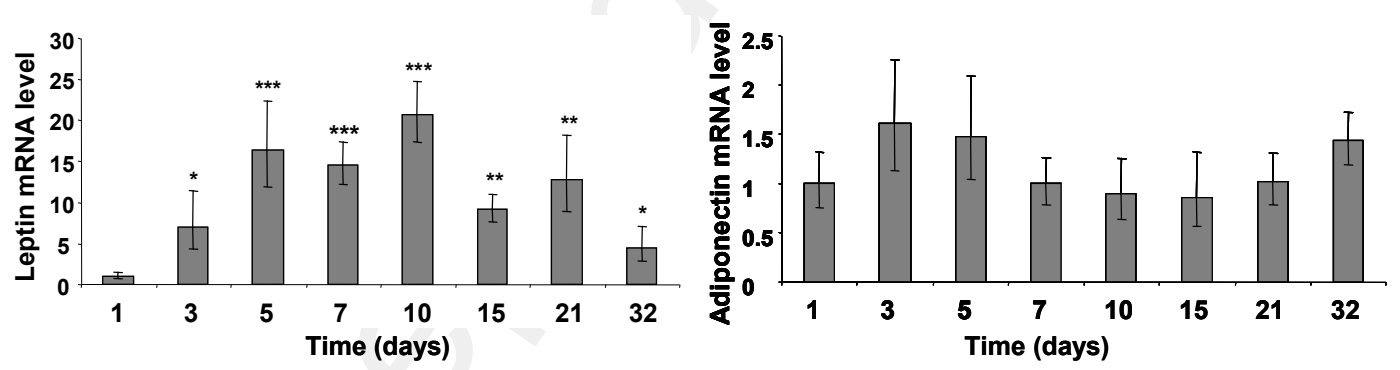

Fig.5. Relative leptin and adiponectin mRNA levels in subcutaneous (A), perirenal (B), and gonadal (C) white fat and BAT (D) of newborn rats, measured by real-time PCR. Results are expressed relative to the levels in each depot at day 1 postnatally or day 5 for perirenal and day 7 for gonadal WAT. Results are presented as means \pm SE (bars) for 5 rats per age group. $* P<0.05, * * P<0.01$ and $* * * P<0.001$ 

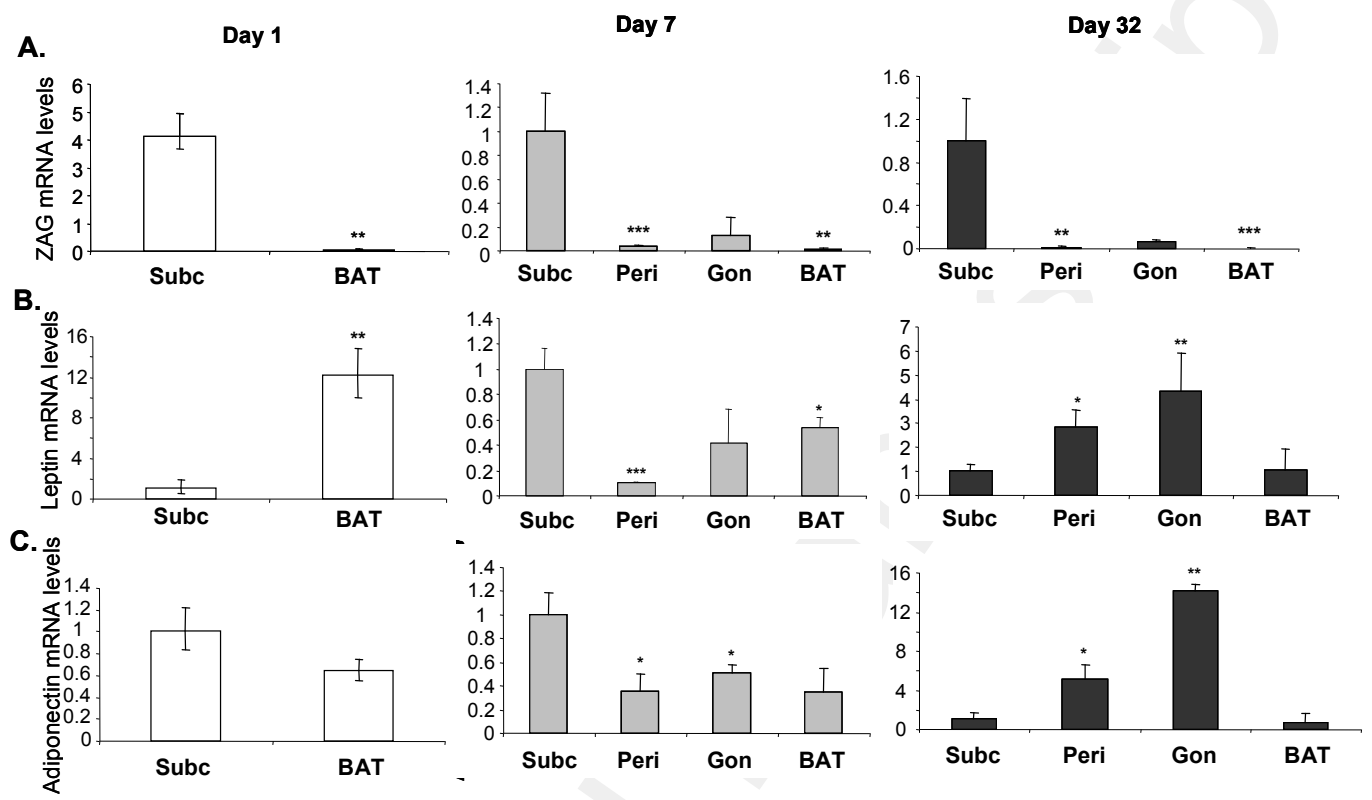

Fig. 6. Relative ZAG (A), leptin (B) and adiponectin (C) mRNA levels were measured in all depots available of newborn rats at days 1, 7 and 32. Results are expressed relative to the levels of each adipokine in subcutaneous WAT at each time point and are presented as means \pm SE for 5 rats per age group. $* P<0.05, * * P<0.01, * * * P<0.001$. 